\title{
Fusobacterial liver abscess: a case report and review of the literature
}

\author{
Dilip Jayasimhan ${ }^{1 *}$, Linus $\mathrm{Wu}^{2}$ and Paul Huggan ${ }^{1 *}$
}

\begin{abstract}
Background: Fusobacteriae are facultative anaerobic gram-negative bacilli which cause a range of invasive infections, amongst which pyogenic liver abscesses are rare. We describe a case of Fusobacterium nucleatum liver abscess and review the relevant literature.

Case presentation: A 51-year-old lady presented with a 4-day history of abdominal pain, diarrhoea, fever, rigors, and lethargy. Imaging revealed an abscess which was drained. Cultures of the blood and abscess aspirate grew Fusobacterium nucleatum and Prevotella pleuritidis respectively. She achieved full recovery following treatment. A MEDLINE search was undertaken using free-text and Medical Subject Headings (MeSH), keywords "Fusobacterium" and "Liver abscess". Non-English language reports and cases without confirmed growth of Fusobacterium species were excluded. Additional cases were identified by surveying the references of each report and by using the same keywords in a web-based search.

Forty-eight cases were identified, 41 in men. The median age was 42.5, with an interquartile range of 33. F. nucleatum and F. necrophorum were in involved in 22 cases each, and 4 cases were not further speciated. Among cases of F. nucleatum liver abscess, nine were attributed to periodontal disease, four to lower gastrointestinal tract disease, one to Lemierre's Syndrome, and eight were considered cryptogenic. All patients treated made a full recovery. Antimicrobial treatment duration ranged from 2 weeks to 6 months with a median of 6 weeks.

Conclusion: Fusobacterium nucleatum is an uncommon cause of liver abscess generally associated with good clinical outcomes with contemporary medical and surgical care.
\end{abstract}

Keywords: Fusobacterium, Liver abscess, Review, Case reports, Lemierre's syndrome, Periodontal diseases

\section{Background}

Fusobacteriae are arguably unique amongst non-spore forming anaerobes in their ability to cause severe, clinically distinct, mono-microbial infections in a range of organs, often with severe sequelae as originally described by Lemierre and others in the first half of the twentieth century [1]. Fusobacterial infections can affect the head and neck, the lung and pleura, the gastro-intestinal organs, and the female genital tract [2]. Despite their ability to cause severe infections, fusobacterium species are uncommonly identified as pathogens in clinical practice, accounting for less than $1 \%$ of anaerobic bacteremias. Regional

\footnotetext{
* Correspondence: d.jayasimhan@gmail.com;

dilip.jayasimhan@waikatodhb.health.nz; Paul.Huggan@waikatodhb.health.nz

'Department of Medicine, Waikato Hospital, Level 2 Waiora Waikato Building,

Pembroke Street, Hamilton 3204, New Zealand

Full list of author information is available at the end of the article
}

population-based studies have described the incidence of Fusobacterial bacteraemia to be around 0.55 per 100,000 people per year $[3,4]$, and that of clinically significant infections to be 0.99 per 100,000 people per year [2]. Whilst the clinical presentations associated with fusobacterial infections are well defined, little is known about the clinical progress and outcomes of specific syndromes $[1,5,6]$. Fusobacteriae are a particularly uncommon cause of pyogenic liver abscesses. Therefore, our objective is to describe a case of this condition and to summarise the presentation and outcomes of Fusobacterial liver abscesses through a review of the relevant literature.

\section{Case presentation}

A 51-year-old previously fit and well woman who recently returned from Samoa presented with a four-day history of watery non-bloody diarrhoea, associated with 
generalised abdominal pain, fevers, chills, and lethargy. Family members reported similar symptoms of milder severity. On admission, she was febrile with a temperature of $38{ }^{\circ} \mathrm{C}$, with otherwise unremarkable vital signs. Examination of the abdomen found a palpable mass in the right upper quadrant. There were no signs of periodontal disease on inspection of the oral cavity. Laboratory tests showed a white cell count of $26.7 \times$ 10E9/L, deranged liver enzymes (alanine transaminase $263 \mathrm{U} / \mathrm{L}$, aspartate transaminase $177 \mathrm{U} / \mathrm{L}$, bilirubin $15 \mathrm{mg} / \mathrm{L}$ ), and a C-reactive protein of $407 \mathrm{mg} / \mathrm{L}$. A Computed Tomography (CT) scan of the abdomen with contrast revealed a $90 \times 92 \times 93 \mathrm{~mm}$ mixed density lesion in segment II and III of the liver The lesion was percutaneously drained under ultrasound guidance. Cultures of the aspirated abscess fluid and blood both grew anaerobic gram-negative bacilli. Following abscess drainage and treatment with ceftriaxone and metronidazole, the patient continued to experience fevers and diarrhoea and her inflammatory markers did not improve. A follow-up ultrasound scan of the liver revealed an emerging focal abscess in segment IV-b of the liver. The initial CT scan was then retrospectively reviewed to reveal subtle heterogeneous changes in this segment; however, no demarcated fluid collection was present at the time. The two abscesses were not contiguous with but in close proximity to each other. This abscess was also percutaneously drained. Samples from the blood culture were further identified as Fusobacterium nucleatum via Biomerieux Vitek (Knowledge database version 2.0) MALDI-TOF (Matrix assisted Laser Desorption/ Ionisation - Time of Flight) mass spectrometry with a confidence of $99.9 \%$. Cultures of the initial aspirate were not identifiable using MALDI-TOF and were referred to a quaternary level laboratory in Auckland and later identified as Prevotella pleuritidis through $16 \mathrm{~s}$ ribosomal Ribonucleic Acid identification. Both specimens underwent susceptibility testing using Clinical Laboratory Standards Institute (CLSI) - recommended media and breakpoint determination using MIC gradient strips. The Prevotella pleuritidis was tested on Brucella agar with sheep blood, haemin, and vitamin K, while the $F$. nucleatum required Brain Heart Infusion agar to achieve satisfactory growth.

Given the growth of a second organism common to the periodontal flora and in the absence of symptoms, signs, or imaging evidence of bowel pathology, a periodontal, rather than a gastrointestinal, source was considered more likely and no further evaluation of the large bowel was undertaken.

Treatment was changed on day nine to a two-week course of IV ertapenem, prior to susceptibilities being known, followed by four further weeks of oral amoxicillin-clavulanate. The patient recovered fully.
Although Fusobacterium was only grown in the blood culture and not in the aspirate culture, we were confident in treating this case as a Fusobacterial pyogenic liver abscess. The aspirate sample was collected afterhours and was not processed until 7 hours later. This delay could have significantly affected our ability to identify this anaerobic organism using standard culture methods, especially in the setting of antimicrobial therapy.

\section{Review of literature}

We conducted a literature review of cases of liver abscess associated with Fusobacterium species.

\section{Methods}

A MEDLINE Medical Subject Headings $\left(\mathrm{MeSH}^{\circ}\right)$ and a free text search were conducted using the keywords "Fusobacterium" AND "liver abscess". The search was further limited to case reports in the English language and on human subjects. Cases in which a liver abscess was demonstrated by appropriate imaging techniques or direct visualization, and was associated with a positive culture (blood, abscess fluid, or tissue) for a Fusobacterium species were included. Additional studies were included through reviewing the references of the selected case reports. One additional case was identified when the same keywords were entered into a web-based search engine (Google TM, San Francisco, CA).

\section{Results}

Forty-eight cases were identified using the above search strategy. Table 1 summarises them. Forty-one cases involved males, and seven involved females. The age of the patients ranged from 17 to 78 years with a median of 42.5 years and an interquartile range of 33 years. Twenty-two cases identified $F$. nucleatum and 22 cases identified $F$. necrophorum as the aetiological pathogen. In another five cases, the microbe was not identified past Fusobacterium spp. 29 of 48 cases involved multiple abscesses as opposed to a single abscess. The most common presumed sources were the periodontal flora (12 cases) and Lemierre's Syndrome (10 cases), followed by the lower GI tract (six cases), the upper GI tract (four cases), and the cervix (one case). Fifteen cases were considered cryptogenic.

Among the cases that identified F. nucleatum, the most common presumed source was the periodontal flora (nine out of 22 cases). Eight cases were cryptogenic. The presumed source was considered to be the lower GI tract in four cases, and Lemierre's syndrome in one case.

Treatment mostly consisted of abscess drainage and prolonged antimicrobial therapy. The duration of 
Table 1 Summary of case reports identified

\begin{tabular}{|c|c|c|c|c|c|c|}
\hline & Age & Sex & Organism (specimen cultured) & Treatment & $\begin{array}{l}\text { Single or } \\
\text { multiple } \\
\text { abscess(es) }\end{array}$ & $\begin{array}{l}\text { Presumed } \\
\text { source }\end{array}$ \\
\hline 1 [35] & 21 & M & $\begin{array}{l}\text { F. nucleatum } \\
\text { (abscess aspirate) }\end{array}$ & $\begin{array}{l}\text { - Drainage of the two largest abscesses (R). } \\
\text { - Piperacillin/tazobactam (UTP) } \\
\text { - Ertapenem (8 weeks) }\end{array}$ & Multiple & Oropharynx (PF) \\
\hline $2[36]$ & 48 & M & $\begin{array}{l}\text { F. nucleatum } \\
\text { (abscess aspirate) }\end{array}$ & $\begin{array}{l}\text { - Drainage of abscess (R) } \\
\text { - Ceftriaxone and metronidazole ( } 3 \text { days) } \\
\text { - IV penicillin and metronidazole ( } 10 \text { weeks) }\end{array}$ & Multiple & Oropharynx (PF) \\
\hline $3[37]$ & 23 & M & F. nucleatum (blood culture and abscess aspirate) & $\begin{array}{l}\text { - Drainage of abscess (R) } \\
\text { - Piperacillin/tazobactam (UTP) } \\
\text { - Ertapenem ( } 6 \text { weeks) }\end{array}$ & Multiple & Unidentified \\
\hline 4 [38] & 58 & M & F. nucleatum (abscess aspirate) & $\begin{array}{l}\text { - Drainage of pelvic abscess (S) } \\
\text { - Defunctioning colostomy } \\
\text { - Ertapenem ( } 6 \text { weeks) } \\
\text { - Low molecular weight heparin (2 weeks) }\end{array}$ & Multiple & $\begin{array}{l}\text { Lower Gl tract } \\
\text { (diverticulitis) }\end{array}$ \\
\hline 5 [39] & 48 & M & F. nucleatum (abscess aspirate) & $\begin{array}{l}\text { - Drainage of two largest abscesses (R) } \\
\text { - Piperacillin/tazobactam ( } 14 \text { days) } \\
\text { - Moxifloxacin + oral penicillin (14 days) }\end{array}$ & Multiple & Unidentified \\
\hline $6[40]$ & 49 & M & F. nucleatum (abscess aspirate) & $\begin{array}{l}\text { - Drainage of largest hepatic abscess(R) } \\
\text { - Laparoscopic cholecystectomy } \\
\text { - Laparoscopic appendicectomy } \\
\text { - IV ertapenem (UTP) }\end{array}$ & Multiple & Oropharynx (PF) \\
\hline 7 [41] & 59 & $\mathrm{~F}$ & $\begin{array}{l}\text { F. nucleatum, Treponema denticola, Prevotella } \\
\text { intermedia, Porphyromonas gingivalis, Bacteroides } \\
\text { vulgatus (tissue culture and abscess apsirate culture) }\end{array}$ & - None & Multiple & Oropharynx (PF) \\
\hline $8[28]$ & 59 & M & F. nucleatum (blood culture) & $\begin{array}{l}\text { - Imipenem/cilastatin } 500 \text { mg BD (4 days) } \\
\text { - Oral clindamycin } 600 \text { mg BD (UTP) }\end{array}$ & Single & Oropharynx (PF) \\
\hline 9 [42] & 58 & M & F. nucleatum (abscess drainage) & $\begin{array}{l}\text { - Drainage of hepatic abscess (R) } \\
\text { - Oral ciprofloxacin, vancomycin, and } \\
\text { gentamicin (UTP) } \\
\text { - IV metronidazole (12 days) } \\
\text { - Oral metronidazole (3 weeks) }\end{array}$ & Single & Oropharynx (PF) \\
\hline 10 [43] & 24 & M & F. nucleatum (blood culture) & $\begin{array}{l}\text { - IV metronidazole (4 weeks) } \\
\text { - Oral metronidazole ( } 2 \text { weeks) }\end{array}$ & Single & $\begin{array}{l}\text { Oropharynx } \\
\text { (PLS) }\end{array}$ \\
\hline $11[44]$ & 62 & M & F. nucleatum (abscess aspirate) & $\begin{array}{l}\text { - Drainage of abscess(NOS) } \\
\text { - IV antibiotics (agent and time period not } \\
\text { specified) }\end{array}$ & Single & $\begin{array}{l}\text { Lower Gl tract } \\
\text { (biopsies) }\end{array}$ \\
\hline $12[45]$ & 78 & $\mathrm{~F}$ & F. nucleatum (abscess aspirate) & $\begin{array}{l}\text { - Drainage of hepatic abscess }(\mathrm{R}) \\
\text { - Drainage of subphrenic collection } \\
\text { - Metronidazole (6 weeks) }\end{array}$ & Single & $\begin{array}{l}\text { Lower Gl tract } \\
\text { (diverticular } \\
\text { disease) }\end{array}$ \\
\hline $13[46]$ & 68 & M & F. nucleatum (blood cultures) & $\begin{array}{l}\text { - IV cefotaxime } 1 \mathrm{~g} \text { Q8H and IV } \\
\text { metronidazole } 500 \text { mg Q8H ( } 24 \text { days) } \\
\text { - Oral metronidazole (2 weeks) } \\
\text { - Enoxaparin } 20 \text { mg daily (UTP) }\end{array}$ & Single & Unidentified \\
\hline $14[47]$ & 54 & $\mathrm{~F}$ & $\begin{array}{l}\text { F. nucleatum (abscess aspirate) } \\
\text { S. viridans (abscess aspirate) } \\
\text { Actinomyces odontolyticus (abscess aspirate) }\end{array}$ & $\begin{array}{l}\text { - Drainage of hepatic abscess (R) } \\
\text { - Extraction of } 11 \text { teeth } \\
\text { - IV antibiotics (agent and period of } \\
\text { treatment unsepciified) }\end{array}$ & Multiple & Oropharynx (PF) \\
\hline $15[47]$ & 69 & M & F. nucleatum (abscess aspirate) & $\begin{array}{l}\text { - Drainage of hepatic abscesses (R) } \\
\text { - IV antibiotics (unspecified agent or time } \\
\text { period) } \\
\text { - Dental surgery }\end{array}$ & Multiple & Oropharynx (PF) \\
\hline $16[48]$ & 40 & M & F. nucleatum (blood culture) & $\begin{array}{l}\text { - IV cefuroxime, metronidazole, and } \\
\text { erythromycin ( } 14 \text { days) } \\
\text { - Oral metronidazole ( } 5 \text { weeks) }\end{array}$ & Multiple & Unidentified \\
\hline 17 [49] & 29 & M & F. nucleatum (abscess aspirate) & $\begin{array}{l}\text { - Drainage of the largest abscess (R) } \\
\text { - Metronidazole (10 days, route unspecified) } \\
\text { - Open drainage other abscesses (S) } \\
\text { - Oral metronidazole (4 weeks) }\end{array}$ & Multiple & Oropharynx (PF) \\
\hline
\end{tabular}


Table 1 Summary of case reports identified (Continued)

\begin{tabular}{|c|c|c|c|c|c|c|}
\hline $18[50]$ & 24 & M & $\begin{array}{l}\text { Actinomyces israeli (abscess aspirate) } \\
\text { F. nucleatum (Abscess aspirate) }\end{array}$ & $\begin{array}{l}\text { - Open drainage of abscess (S) } \\
\text { - Penicillin G } 20 \text { million units (4 weeks) } \\
\text { - Oral penicillin (6 months) }\end{array}$ & Single & Unidentified \\
\hline 19 [51] & 70 & M & F. nucleatum (abscess aspirate) & $\begin{array}{l}\text { - Metronidazole ( } 2 \text { weeks, route unspecified) } \\
\text { - Oral metronidazole ( } 2 \text { weeks) }\end{array}$ & Multiple & Unidentified \\
\hline $20[52]$ & 47 & M & $\begin{array}{l}\text { F. nucleatum (tissue culture) } \\
\text { Peptostreptococcus (tissue culture) }\end{array}$ & $\begin{array}{l}\text { - Open resection of all three lesions. (S) } \\
\text { - IV penicillin ( } 3 \text { weeks) } \\
\text { - Repeat laparotomy } 49 \text { days later } \\
\text { - PO penicillin (4 months) }\end{array}$ & Multiple & Unidentified \\
\hline $21[53]$ & 44 & $\mathrm{~F}$ & $\begin{array}{l}\text { F. nucleatum } \\
\text { (blood culture) }\end{array}$ & $\begin{array}{l}\text { - Drainage of abscess (R) } \\
\text { - Imipenem and metronidazole (UTP) } \\
\text { - Cefotaxime and metronidazole (13 days) } \\
\text { - Ceftriaxone and oral metronidazole } \\
\text { ( } 5 \text { weeks) }\end{array}$ & Single & Unidentified \\
\hline $22[54]$ & 60 & M & F. nucleatum (abscess aspirate) & $\begin{array}{l}\text { - Piperacillin/tazobactam (3 days) } \\
\text { - Ertapenem (1 day) } \\
\text { - Moxifloxacin (10 days) } \\
\text { - Metronidazole (3 weeks) }\end{array}$ & Multiple & $\begin{array}{l}\text { Lower Gl tract } \\
\text { (diverticulitis) }\end{array}$ \\
\hline 23 [55] & 28 & M & $\begin{array}{l}\text { F. necrophorum } \\
\text { (blood culture) }\end{array}$ & $\begin{array}{l}\text { - Ceftriaxone (6 days) } \\
\text { - Meropenem (14 days) }\end{array}$ & Single & $\begin{array}{l}\text { Oropharynx } \\
(P L S)\end{array}$ \\
\hline $24[56]$ & 30 & M & F. necrophorum (blood culture) & $\begin{array}{l}\text { - Piperacillin/tazobactam and metronidazole } \\
\text { (UTP) } \\
\text { - Oral levofloxacin and metronidazole (UTP) }\end{array}$ & Multiple & Unidentified \\
\hline $25[57]$ & 48 & M & F. necrophorum (blood culture) & $\begin{array}{l}\text { - Cefotiam (UTP) } \\
\text { - Doripenem (19 days) } \\
\text { - Oral levofloxacin (UTP) }\end{array}$ & Multiple & $\begin{array}{l}\text { Oropharynx } \\
\text { (PLS) }\end{array}$ \\
\hline $26[29]$ & 40 & M & F. necrophorum (tissue culture) & $\begin{array}{l}\text { - Drainage of abscess (R) } \\
\text { - Sulbactam/cefoperazone (10 days) } \\
\text { - Meropenem ( } 9 \text { days) } \\
\text { - Oral sawacillin (8 weeks) }\end{array}$ & Single & Unidentified \\
\hline $27[58]$ & 25 & M & $\begin{array}{l}\text { F. necrophorum } \\
\text { (blood culture) }\end{array}$ & $\begin{array}{l}\text { - Piperacillin/tazobactam (UTP) } \\
\text { - IV penicillin (6 weeks) }\end{array}$ & Single & $\begin{array}{l}\text { Oropharynx } \\
(P L S)\end{array}$ \\
\hline $28[59]$ & 34 & M & F. necrophorum (left subphrenic collection) & $\begin{array}{l}\text { - Vancomycin and meropenem (UTP) } \\
\text { - Tigecyclin and meropenem (UTP) } \\
\text { - Tigecyclin (4 weeks) }\end{array}$ & Multiple & $\begin{array}{l}\text { Upper Gl tract } \\
\text { (HPB) }\end{array}$ \\
\hline $29[60]$ & 44 & F & F. necrophorum (blood culture) & $\begin{array}{l}\text { - IV ampicillin/sulbactam and ciprofloxacin } \\
\text { (5 days) } \\
\text { - IV ampicillin/sulbactam and metronidazole } \\
\text { (13 days) } \\
\text { - IV ampicillin/sulbactam (15 days) } \\
\text { - Oral amoxicillin/clavulanate (1 month) }\end{array}$ & Single & Cervix \\
\hline $30[61]$ & 18 & M & F. necrophorum (blood culture) & $\begin{array}{l}\text { - Aspiration of abscess (R) } \\
\text { - Metronidazole and cefuroxime (UTP) } \\
\text { - Piperacillin/tazobactam + clindamycin } \\
\quad \text { (5 weeks) }\end{array}$ & Single & $\begin{array}{l}\text { Oropharynx } \\
(P L S)\end{array}$ \\
\hline $31[62]$ & 21 & M & $\begin{array}{l}\text { F. necrophorum (abscess drainage) } \\
\text { F. nucleatum (peritonsillar abscess) }\end{array}$ & $\begin{array}{l}\text { - Drainage of the largest hepatic abscess (R) } \\
\text { - Piperacillin/tazobactam and metronidazole } \\
\text { (6 weeks) }\end{array}$ & Multiple & $\begin{array}{l}\text { Oropharynx } \\
\text { (PLS) }\end{array}$ \\
\hline 32 [10] & 25 & M & $\begin{array}{l}\text { F. necrophorum (abscess aspirate) } \\
\text { Prevotella spp. (blood culture and abscess aspirate) }\end{array}$ & $\begin{array}{l}\text { - Drainage of abscess } \\
\text { - Removal of diseased teeth } \\
\text { - Oral amoxicillin/clavulanate (3 weeks) }\end{array}$ & SIngle & Oropharynx (PF) \\
\hline $33[11]$ & 64 & M & F. necrophorum (abscess aspirate) & $\begin{array}{l}\text { - Aspiration of abscess (R) } \\
\text { - Cefuroxime and metronidazole (2 weeks) } \\
\text { - Oral metronidazole and oral ciprofloxacin } \\
\text { (UTP) }\end{array}$ & Multiple & $\begin{array}{l}\text { Lower Gl tract } \\
\text { (haemorrohoids) }\end{array}$ \\
\hline $34[63]$ & 22 & M & F. necrophorum (abscess aspirate) & $\begin{array}{l}\text { - Aspiration of abscess (R) } \\
\text { - Gentamicin, clarithormycin, metronidazole, } \\
\text { ceftriaxone and low molecular weight }\end{array}$ & Multiple & $\begin{array}{l}\text { Oropharynx } \\
\text { (PLS) }\end{array}$ \\
\hline
\end{tabular}


Table 1 Summary of case reports identified (Continued)

\begin{tabular}{|c|c|c|c|c|c|c|}
\hline $35[64]$ & 19 & $\mathrm{~F}$ & F. necrophorum (blood culture and abscess aspirate) & $\begin{array}{l}\text { - Drainage of the largest hepatic abscess } \\
\text { - IV benzylpenicillin, metronidazole, and } \\
\text { ciprofloxacin ( } 5 \text { weeks) }\end{array}$ & Multiple & $\begin{array}{l}\text { Oropharynx } \\
\text { (PLS) }\end{array}$ \\
\hline $36[65]$ & 71 & M & F. necrophorum (abscess aspirate) & $\begin{array}{l}\text { - IV benzylpenicillin ( } 6 \text { weeks) } \\
\text { - Oral amoxicillin ( } 6 \text { weeks) }\end{array}$ & Multiple & $\begin{array}{l}\text { Lower Gl } \\
\text { (diverticular } \\
\text { disease) }\end{array}$ \\
\hline 37 [66] & 44 & M & $\begin{array}{l}\text { F. necrophorum (abscess aspirate) } \\
\text { H. Parainfluenzae (abscess aspirate) }\end{array}$ & $\begin{array}{l}\text { - Drainage of hepatic abscess (R) } \\
\text { - IV tetracycline (3 days) } \\
\text { - Co-trimoxazole ( } 8 \text { days) } \\
\text { - IV cefazolin + IV gentamicin (UTP) } \\
\text { - IV ceftriaxone (3 weeks) }\end{array}$ & Single & Unidentified \\
\hline 38 [67] & 18 & M & F. necrophorum (blood culture) & $\begin{array}{l}\text { - Cefotaxime, vancomycin, and azithromycin. } \\
\text { Then cefepime and metronidazole } \\
\text { (unspecified chronology or time period) }\end{array}$ & Single & $\begin{array}{l}\text { Oropharynx } \\
\text { (PLS) }\end{array}$ \\
\hline 39 [68] & 17 & $\mathrm{~F}$ & F. necrophorum (blood culture) & $\begin{array}{l}\text { - Nafcillin and ceftriaxone ( } 3 \text { days) } \\
\text { - Nafcillin, ceftriaxone, and metronidazole } \\
\text { ( } 6 \text { weeks) }\end{array}$ & Multiple & $\begin{array}{l}\text { Oropharynx } \\
\text { (PLS) }\end{array}$ \\
\hline $40[69]$ & 27 & M & $\begin{array}{l}\text { F. necrophorum (blood cultures } \\
\text { and abscess aspirate) }\end{array}$ & $\begin{array}{l}\text { - Drainage of hepatic abscess (R) } \\
\text { - IV ampicillin, gentamicin, and } \\
\text { metornidazole (10 days) } \\
\text { - Oral ampicillin and metronidazole } \\
\text { (5 weeks) }\end{array}$ & Single & $\begin{array}{l}\text { Oropharynx } \\
(P L S)\end{array}$ \\
\hline $41[70]$ & 55 & M & F. necrophorum (abscess aspirate) & $\begin{array}{l}\text { - Aspiration of abscess } \\
\text { - IV ampicillin/sulbactam (1 month) } \\
\text { - Oral amoxicillin/clavulanate (21 days) }\end{array}$ & Multiple & $\begin{array}{l}\text { Upper Gl tract } \\
\text { (HPB) }\end{array}$ \\
\hline $42[71]$ & 31 & M & F. necrophorum (abscess aspirate) & $\begin{array}{l}\text { - Open drainage of abscesses (S) } \\
\text { - Gentamicin, clindamycin, and doxicycline } \\
\text { (15 days) } \\
\text { - Further open drainage of abscess (S) } \\
\text { - IV chloremphenicol and metronidazole } \\
\text { (3 weeks) }\end{array}$ & Multiple & Unidentified \\
\hline $43[72]$ & 36 & M & $\begin{array}{l}\text { F. necrophorum (abscess aspirate } \\
\text { and blood culture) }\end{array}$ & $\begin{array}{l}\text { - Drainage of hepatic abscesses (R) } \\
\text { - Ceftriaxone } 2 \mathrm{~g} \text { Q24H (UTP) } \\
\text { - Ampicillin/sulbactam } 12 \mathrm{~g} / \text { day (UTP) }\end{array}$ & Multiple & Oropharynx (PF) \\
\hline 44 [73] & 57 & M & F. necrophorum (abscess aspirate) & $\begin{array}{l}\text { - Drainage of abscess (R) } \\
\text { - Metronidazole (7 days) and ceftriaxone } \\
\text { (UTP) } \\
\text { - Piperacillin/tazobactam (4 weeks) }\end{array}$ & Single & Oropharynx (PF) \\
\hline $45[74]$ & 34 & M & Fusobacterium spp. (abscess aspirate) & $\begin{array}{l}\text { - Drainage of largest abscess with } \\
\text { gentamicin flushes. (R) } \\
\text { - Drainage of subdiaphragmatic collection } \\
\text { (R) } \\
\text { - Aspiration of smaller abscesses. (R) } \\
\text { - Imipenem (22 days) }\end{array}$ & Multiple & $\begin{array}{l}\text { Upper Gl tract } \\
\text { (Crohn's } \\
\text { Disease) }\end{array}$ \\
\hline $46[16]$ & 69 & M & Fusobacterium spp. (liver biopsy) & $\begin{array}{l}\text { - Piperacillin and metronidazole ( } 3 \text { weeks) } \\
\text { - Oral amoxicillin/clavulanate and } \\
\text { metronidazole ( } 2 \text { months) }\end{array}$ & Multiple & Unidentified \\
\hline $47[75]$ & 41 & M & Fusobacterium spp. (abscess aspirate) & $\begin{array}{l}\text { - Drainage of hepatic abscess (R) } \\
\text { - Cefomandole, gentamicin, and } \\
\text { metronidazole (UTP) } \\
\text { - Penicillin (1 month) }\end{array}$ & Single & $\begin{array}{l}\text { Upper GI tract } \\
\text { (diverticulitis of } \\
\text { terminal lleum) }\end{array}$ \\
\hline 48 [76] & 22 & M & Fusobacterium Spp (blood cultures) & - Penicillin (31 days) & Multiple & Unidentified \\
\hline
\end{tabular}

treatment was specified in 39 cases. Among them, the minimum duration was 2 weeks, and the maximum was 6 months, with a median of 6 weeks, and an interquartile range of 2 weeks. The duration was less than 4 weeks in five cases, between four to 8 weeks in 26 cases, and more than 8 weeks in eight case. Commonly used antibiotics include beta-lactams (in combination with metronidazole in some cases), carbapenems, metronidazole monotherapy, and less frequently fluoroquinolones.

Treatment outcomes were favourable with 47 of 48 cases reporting complete recovery. 


\section{Discussion}

Whilst the essential features of disease caused by Fusobacteriae have been recognised for over a century, presentations remain uncommon and widely distributed across medical specialties [1]. Thus the historical background, aetiopathogenesis, and likely clinical outcomes of fusobacterial disease are poorly understood by most clinicians. This report demonstrates the common features of fusobacterial liver abscess and by combining individual reports and case series provides insights into the associated spectrum of underlying illness.

Loeffler identified a thin, gram-negative rod present in necrotic tissue in calf diptheriae in 1884 [7]. The term 'necrobacillosis' was coined by Bang, who isolated the organism from diseased cattle and pigs [8]. Koch's postulates were satisfied accidentally when Schmorl and an assistant suffered pyogenic infection of their fingers whilst working with diseased rabbits, samples from both of which yielded Fusobacteriae [5]. Cases of de novo necrobacillosis were described in humans by the turn of the twentieth century. Lemierre gave his classic dissertation on anaerobic bacteremia in 1936, earning the right to an eponymous syndrome of tonsillar abscess progressing to internal jugular vein thrombosis, distant abscess formation, and overwhelming sepsis [9].

In the twentieth century it was axiomatic, based on very little evidence, that Fusobacteriae were part of the normal human oropharyngeal, gastro-intestinal (GI) tract and female genital tract flora. The apparent rarity of illness caused by these organisms reinforced the notion that they were opportunists, causing illness only when natural barriers to infection were compromised [1, 10, 11]. Contemporary studies have shed light on the true environmental niche and pathogenic potential of Fusobacteriae in general and Fusobacterium nucleatum specifically. Fusobacterium nucleatum is a major constituent of the gingival, oropharyngeal and together with $F$. necrophorum, the appendiceal flora. Neither organism is a component of the healthy colonic flora nor do they form a major component of the healthy vaginal micro-biome $[1,12,13]$. F. necrophorum was found to exist in the healthy oropharyngeal flora in only one polymerase chain reaction (PCR) based study reported and in none of the culture-based studies [1]. Gingivo-periodontitis, endodontic infection and suppurative appendicitis occur in the setting of clonal expansion and invasion of Fusobacteriae, and it has been postulated that adverse obstetric outcomes arise from haematogenous spread of F. nucleatum to placental tissue $[14,15]$. Prevotella pleuritidis was identified in the case we described and the gingival/ oropharyngeal flora were identified as co-pathogens in $18 \%$ of liver abscess caused by F. nucleatum in our review of the literature.
Indeed, our review of fusobacterial pyogenic liver abscesses showed a low prevalence of general risk factors for liver abscess including malignancy, dialysis treatment, and older age [4]. Most cases occurred in young or middle-aged, immunocompetent individuals with risk factors for haematogenous spread of Fusobacteriae such as periodontal disease and recent pharyngitis.

Attribution of the lower GI tract as a source of liver abscess was relatively uncommon and the grounds for doing so were often unclear. The utility of investigating for a presumed source is unknown at this point due to the lack of research assessing this particular question. Our findings support the contention that the majority of disseminated fusobacterial infections originate from the oral cavity even without symptoms of a dental disease. Dental $\mathrm{X}$-Rays to identify possible dental abscesses and cavities or more sophisticated imaging modalities of the oral cavity and the sinuses may be of the most benefit, should clinicians choose to investigate the underlying sources of bacteremia in patients without localising symptoms [16].

Among cases where F. necrophorum were cultured, only three of the 23 liver abscesses were associated with a co-pathogen. None of these cases had clinical findings consistent with classic Lemierre syndrome. Whilst the environmental niche of $F$. necrophorum is less understood than that of F. nucleatum, it is among the most commonly identified cause of tonsillar abscess after Lancefield Group A beta-hemolytic streptococci $[17,18]$. This potentially points to a more evolved role for F. necrophorum as a human pathogen.

We observed good outcomes with appropriate source control and antimicrobial therapy. The only case involving a fatality was a post-mortem diagnosis and treatment had not been initiated. There was significant variation between studies with regards to the choice and duration of antimicrobial therapy. Current evidence suggests the need for prolonged antimicrobial therapy for patients with liver abscess and risk factors for treatment failure. These include malignancy, older age, presence of septic shock at presentation, certain biochemical derangements (e.g. anaemia, azotaemia, and hyperbilirubinaemia), and an Acute Physiology and Chronic Health Evaluation (APACHE) II score of more than 15 [19-21].

Routine prolonged broad-spectrum antimicrobial therapy may not be warranted in cases of fusobacterial liver abscess with a presumed oral or periodontal origin, especially in the setting of abscess drainage. Fusobacteriae remain highly susceptible to beta-lactams. Studies on susceptibility patterns have shown no increase in amoxicillin-resistant Fusobacteriae over the past decade [22-24]. They are unlikely to be accompanied by highly resistant co-pathogens in polymicrobial infection of oral or periodontal origin. Metronidazole has been associated with good clinical responses in the treatment of fusobacterial and mixed 
anaerobic infections [25]. Where source control is achieved, and with the aid of reliable clinical biomarkers such as C-reactive protein, antimicrobial therapy may be shortened [26, 27]. Further research into shorter course therapy for highly sensitive organisms such as Fusobacteriae could better delineate optimal antimicrobial treatment duration for patients with liver abscesses.

The strengths of this review are that it employed an extensive search strategy to identify a greater number of cases than previous reviews on the same topic. Previous literature reviews of case reports have focused mainly on only one Fusobacteriae species (F. necrophorum or $F$. nucleatum) $[28,29]$. To our knowledge, this is the first review to include all Fusobacteriae spp., to demonstrate their homogeneity in clinical presentation, clinical findings, co-pathogens and outcomes.

Our study has several weaknesses. The main weakness is that in the case presented, Fusobacterium nucleatum was identified in the blood culture but not in the abscess aspirate. We remain confident in attributing F.nucleatum as a causative co-pathogen for a number of reasons. Firstly, delays in sample processing have been known to increase the difficulty in identifying anaerobes through conventional culture methods [30], especially in the setting of antimicrobial therapy, which was commenced in advance of abscess drainage. Studies using pyrosequencing of direct samples have shown that pyogenic abscesses are frequently polymicrobial, with the number of aetiologic agents identified significantly exceeding what is achieved using standard culture-based methods [30, 31]. Secondly, many population-based studies accept blood cultures as an appropriate standard in diagnosing causative organisms and in guiding antimicrobial treatment in pyogenic liver abscess [32]. Some cases included in our review identified Fusobacteriae by blood culture alone [33, 34]. Therefore, we have grounds to believe that $F$. nucleatum was indeed a causative agent.

In terms of other weaknesses, we reported only published observations; publications may have been biased towards those of specific interest to a journal's readership or those that were associated with good clinical outcomes. Cases in languages other than English were excluded. Attribution of underlying source was presumptive rather than definitive in a significant number of case series. Furthermore, there was minimal information on microbiologic methods. This may have led to an over-reporting of mono-microbial infection, for example, where culturebased methods lacked sensitivity or where growth of the anaerobic flora at low quantities was under-reported.

\section{Conclusion}

In this case report and review of the literature, we found that fusobacterial liver abscesses resulted in good outcomes with contemporary medical and surgical care.

\section{Abbreviations}

BD: Twice daily; CLSI: Clinical Laboratory Standards Institute; CT: Computed tomography; DNA: Deoxyribonucleic acid; Gl: Gastrointestinal; IV: Intravenous; L: Litre; LS: Lemierre's syndrome; mg: Milligrams; mm: Millimetre;

PCR: Polymerase chain reaction; PF: Periodontal flora; R: Radiological drainage; S: Surgical drainage; U: Units; UTP: Unspecified time period

\section{Acknowledgments}

We acknowledge the help of Chris Mansell and Sean Edward Munroe of Waikato Hospital Laboratory who provided us with details of the logistics and methods of microbiological sample processing, Marion Smith, at LabPlus Auckland, who performed the susceptibility testing and provided us with the information on the methods used to identify Prevotella pleuritidis, as well as Graham Mills and Rennie Qin for their feedback on the final manuscript.

Availability of data materials

Available from corresponding author on reasonable request.

Funding

Not applicable

Authors' contributions

DJ and PH conceived the study and developed the search strategy. DJ conducted the review of relevant articles, and produced the first draft of manuscript. LW was the primary clinician involved in the case and provided input into the case. PH provided significant input into editing the overall manuscript and developing the discussion. All authors read and approved the final manuscript.

\section{Competing interests}

The authors declare that they have no competing interests.

\section{Consent for publication}

Written consent for potentially identifying information being published as a case report obtained from patient during admission. Consent was also reconfirmed verbally prior to submission of written article for publication.

Ethics approval and consent to participate Not applicable

\section{Publisher's Note}

Springer Nature remains neutral with regard to jurisdictional claims in published maps and institutional affiliations.

\section{Author details}

'Department of Medicine, Waikato Hospital, Level 2 Waiora Waikato Building, Pembroke Street, Hamilton 3204, New Zealand. ²Department of General Surgery, Waikato Hospital, Level 2 Waiora Waikato Building, Pembroke Street, Hamilton 3204, New Zealand.

Received: 27 February 2017 Accepted: 13 June 2017

Published online: 20 June 2017

\section{References}

1. Riordan T. Human infection with Fusobacterium necrophorum (Necrobacillosis), with a focus on Lemierre's syndrome. Clin Microbiol Rev. 2007:20:622-59.

2. Huggan PJ, Murdoch DR. Fusobacterial infections: clinical spectrum and incidence of invasive disease. J Inf Secur. 2008:57:283-9.

3. Hagelskjaer Kristensen L, Prag J. Lemierre's syndrome and other disseminated Fusobacterium necrophorum infections in Denmark: a prospective epidemiological and clinical survey. Eur J Clin Microbiol Infect Dis. 2008:27:779-89.

4. Afra K, Laupland K, Leal J, Lloyd T, Gregson D. Incidence, risk factors, and outcomes of Fusobacterium species bacteremia. BMC Infect Dis. 2013;13:264.

5. Brazier JS. Human infections with Fusobacterium necrophorum. Anaerobe 2006;12:165-72.

6. Citron DM. Update on the taxonomy and clinical aspects of the genus fusobacterium. Clin Infect Dis. 2002;35:S22-7.

7. Pappenheimer AM. The diphtheria bacillus and its toxin: a model system. J Hyg (Lond). 1984;93:397-404. 
8. Hagelskjaer Kristensen L, Prag J. Human necrobacillosis, with emphasis on Lemierre's syndrome. Clin Infect Dis. 2000;31:524-32.

9. Lemierre A. On certain septicæmias due to anaerobic organisms. Lancet. 1936;227:701-3

10. Lei W-Y, Chang W-H, Shih S-C, Liu C-J, Shih C-H. Pyogenic liver abscess with Prevotella species and Fusobacterium necrophorum as causative pathogens in an immunocompetent patient. J Formos Med Assoc. 2009;108:253-7.

11. Ergas D, Abdul-Hai A, Sthoeger Z, Menahem B-H, Miller R. Multiple pyogenic liver abscesses following hemorrhoid banding. Isr Med Assoc J. 2007;9:753-4.

12. Ma B, Forney $L$, Ravel J. Vaginal microbiome: rethinking health and disease. Annu Rev Microbiol. 2012;66:371-89.

13. Segata N, Haake SK, Mannon P, Lemon KP, Waldron L, Gevers D, et al. Composition of the adult digestive tract bacterial microbiome based on seven mouth surfaces, tonsils, throat and stool samples. Genome Biol. 2012;13:R42.

14. Swidsinski A, Dörffel $Y$, Loening-Baucke $V$, Theissig F, Rückert JC, Ismail M, et al. Acute appendicitis is characterised by local invasion with Fusobacterium nucleatum/necrophorum. Gut. 2011;60:34-40.

15. Han YW. Fusobacterium nucleatum: a commensal-turned pathogen. Curr Opin Microbiol. 2015;23:141-7.

16. Bauer C, Schoonbroodt D, Wagner C, Horsmans Y. Liver abscesses due to Fusobacterium species. Liver. 2000;20:267-8.

17. Ehlers Klug T, Rusan M, Fuursted K, Ovesen T. Fusobacterium necrophorum: most prevalent pathogen in peritonsillar abscess in Denmark. Clin Infect Dis. 2009:49:1467-72

18. Batty A, Wren MWD. Prevalence of Fusobacterium necrophorum and other upper respiratory tract pathogens isolated from throat swabs. Br J Biomed Sci. 2005;62:66-70

19. Lo JZW, Leow JJ, Ng PLF, Lee HQ, Mohd Noor NA, Low JK, et al. Predictors of therapy failure in a series of 741 adult pyogenic liver abscesses. J Hepatobiliary Pancreat Sci. 2015;22:156-65.

20. Barakate MS, Stephen MS, Waugh RC, Gallagher PJ, Solomon MJ, Storey DW, et al. Pyogenic liver abscess: a review of 10 years' experience in management. Aust N Z J Surg. 1999:69:205-9.

21. Meddings L, Myers RP, Hubbard J, Shaheen AA, Laupland KB, Dixon E, et al. A population-based study of pyogenic liver abscesses in the United States: incidence, mortality, and temporal trends. Am J Gastroenterol. 2010;105:117-24.

22. Veloo ACM, van Winkelhoff AJ. Antibiotic susceptibility profiles of anaerobic pathogens in The Netherlands. Anaerobe. 2015;31:19-24.

23. Boyanova L, Kolarov R, Mitov I. Recent evolution of antibiotic resistance in the anaerobes as compared to previous decades. Anaerobe. 2015;31:4-10.

24. Jamal W, Al Hashem G, Rotimi VO. Antimicrobial resistance among anaerobes isolated from clinical specimens in Kuwait hospitals: comparative analysis of 11-year data. Anaerobe. 2015;31:25-30.

25. Löfmark S, Edlund C, Nord CE. Metronidazole is still the drug of choice for treatment of anaerobic infections. Clin Infect Dis. 2010;50(Suppl 1):S16-23.

26. Rahimian J, Wilson T, Oram V, Holzman RS. Pyogenic liver abscess: recent trends in etiology and mortality. Clin Infect Dis. 2004;39:1654-9.

27. Gao H-N, Yuan W-X, Yang M-F, Zhao H, Hu J-H, Zhang X, et al. Clinical significance of $C$-reactive protein values in antibiotic treatment for pyogenic liver abscess. World J Gastroenterol. 2010;16:4871-5.

28. Kajiya T, Uemura T, Kajiya M, Kaname H, Hirano R, Uemura N, et al. Pyogenic liver abscess related to dental disease in an immunocompetent host. Intern Med. 2008;47:675-8.

29. Nozawa Y, Joshita S, Fukushima M, Sugiyama Y, Ichikawa Y, Kimura T, et al. A case of pyogenic liver abscess infected with Fusobacterium necrophorum depicted by microscopy and confirmed by tissue culture. Intern Med. 2011;50:1815-9.

30. Sibley CD, Church DL, Surette MG, Dowd SE, Parkins MD. Pyrosequencing reveals the complex polymicrobial nature of invasive pyogenic infections: microbial constituents of empyema, liver abscess, and intracerebral abscess. Eur J Clin Microbiol Infect Dis. 2012;31:2679-91.

31. Song YG, Shim SG, Kim KM, Lee D-H, Kim D-S, Choi S-H, et al. Profiling of the bacteria responsible for pyogenic liver abscess by $16 \mathrm{~S}$ rRNA gene pyrosequencing. J Microbiol. 2014;52:504-9.

32. Abbas MT, Khan FY, Muhsin SA, Al-Dehwe B, Abukamar M, Elzouki A-N. Epidemiology, Clinical Features and Outcome of Liver Abscess: A single Reference Center Experience in Qatar. Oman Med J. 2014;29:260-3.

33. Luo M, Yang X-X, Tan B, Zhou X-P, Xia H-M, Xue J, et al. Distribution of common pathogens in patients with pyogenic liver abscess in China: a meta-analysis. Eur J Clin Microbiol Infect Dis. 2016;35:1557-65.
34. Chen C-H, Wu S-S, Chang H-C, Chang Y-J. Initial presentations and final outcomes of primary pyogenic liver abscess: a cross-sectional study. BMC Gastroenterol. 2014;14:133

35. Ahmed Z, Bansal SK, Dhillon S. Pyogenic liver abscess caused by Fusobacterium in a 21-year-old immunocompetent male. World $J$ Gastroenterol. 2015;21:3731-5.

36. Dahya V, Patel J, Wheeler M, Ketsela G. Fusobacterium nucleatum endocarditis presenting as liver and brain abscesses in an immunocompetent patient. Am J Med Sci. 2015;349:284-5.

37. Kearney A, Knoll B. Myopericarditis associated with Fusobacterium nucleatum-caused liver abscess. Infect Dis (Lond). 2015:47:187-9.

38. Schattner A, Gotler J. Fever, night sweats, and abnormal liver enzymes. Lancet. 2014:384:376.

39. Rashidi A, Tahhan SG, Cohee MW, Goodman BM. Fusobacterium nucleatum infection mimicking metastatic cancer. Indian J Gastroenterol. 2012;31:198-200

40. To C, Napolitano J. A multiple choice answer? J Hosp Med. 2011;6:171-2.

41. Ohyama H, Nakasho K, Yamanegi K, Noiri Y, Kuhara A, Kato-Kogoe N, et al. An unusual autopsy case of pyogenic liver abscess caused by periodontal bacteria. Jpn J Infect Dis. 2009:62:381-3.

42. Cigarrán S, Neches C, Lamas JM, García-Trio G, Alonso M, Saavedra J. A case report of a pyogenic liver abscess caused by Fusobacterium nucleatum in a patient with autosomal dominant polycystic kidney disease undergoing hemodialysis. Ther Apher Dial. 2008;12:91-5.

43. Cheung WY, Bellas J. Fusobacterium: elusive cause of life-threatening septic thromboembolism. Can Fam Physician. 2007;53:1451-3.

44. Wells CD, Balan V, Smilack JD. Pyogenic liver abscess after colonoscopy in a patient with ulcerative colitis. Clin Gastroenterol Hepatol. 2005;3:xxiv.

45. Ala A, Safar-Aly H, Millar A. Metallic cough and pyogenic liver abscess. Eur J Gastroenterol Hepatol. 2001;13:967-9.

46. Etienne M, Gueit I, Abboud P, Pons JL, Jacquot S, Caron F. Fusobacterium nucleatum hepatic abscess with pylephlebitis associated with idiopathic CD4(+) T Iymphocytopenia. Clin Infect Dis. 2001;32:326-8.

47. Crippin JS, Wang KK. An unrecognized etiology for pyogenic hepatic abscesses in normal hosts: dental disease. Am J Gastroenterol. 1992:87:1740-3.

48. Scoular A, Corcoran GD, Malin A, Evans BA, Davies A, Miller RF. Fusobacterium nucleatum bacteraemia with multiple liver abscesses in an HIV-I antibody positive man with IgG2 deficiency. J Inf Secur. 1992;24:321-5.

49. Tweedy CR, White WB. Multiple Fusobacterium nucleatum liver abscesses. Association with a persistent abnormality in humoral immune function. J Clin Gastroenterol. 1987:9:194-7.

50. Gertsch P, Diserens H, Mosimann R. Superinfected actinomycotic abscess of the liver. Int Surg. 1985;70:39-40.

51. Ralph ED. Successful antimicrobial therapy of hepatic, intra-abdominal and intrapelvic abscesses. Can Med Assoc J. 1984;131:605-7.

52. Young EJ, Harper WK, Taylor RL. Hepatic necrobacillosis. Report of a case resembling metastatic tumor. Arch Intern Med. 1977;137:804-7.

53. Wilson R, LeBlanc R, Hamour AA. Cryptogenic pyogenic liver abscess due to Fusobacterium nucleatum: A case report. BCMJ. 2016;56:130-4.

54. Wijarnpreecha K, Yuklyaeva N, Sornprom S, Hyman C. Fusobacterium Nucleatum: Atypical Organism of Pyogenic Liver Abscess Might be Related to Sigmoid Diverticulitis. N Am J Med Sci. 2016;8:197-9.

55. Takano Y, Fukuda K, Takayasu H, Shinmura K, Koizumi G, Sasai M, et al. Liver abscessation and multiple septic pulmonary emboli associated with Lemierre's syndrome: a case report. BMC Res Notes. 2015;8:65.

56. Fatakhov E, Patel MK, Santha S, Koch CF. Fusobacterium necrophorum: a rare cause of hepatic abscess in an immunocompetent individual. BM. Case Rep. 2013;2013. doi:10.1136/bcr-2013-200748.

57. Iwasaki T, Yamamoto T, Inoue K, Takaku K. A case of Lemierre's syndrome in association with liver abscess without any other metastatic lesions. Intern Med. 2012:51:1419-23.

58. Handler MZ, Miriovsky B, Gendelman HE, Sandkovsky U. Fusobacterium necrophorum causing infective endocarditis and liver and splenic abscesses. Rev Inst Med Trop Sao Paulo. 2011;53:169-72.

59. Shahani $L$, Khardori N. Fusobacterium necrophorum-beyond Lemierres syndrome. BMJ Case Rep. 2011;2011. doi:10.1136/bcr.07.2011.4527.

60. Treszezamsky AD, Molina Boero MF, Mehta I. Cervical conization complicated by sepsis with lung and liver abscesses. J Low Genit Tract Dis. 2010;14:130-3.

61. Thoufeeq MH, Salloum W, Win SS, Sinha L. Lemierre's syndrome secondary to Fusobacterium necrophorum infection, a rare cause of hepatic abscess. Acta Gastroenterol Belg. 2009;72:444-6. 
62. David H. A 21-year-old man with fever and abdominal pain after recent peritonsillar abscess drainage. Am J Emerg Med. 2009;27:515.e3-4.

63. Thatcher P. Hepatic abscesses caused by Fusobacterium necrophorum as part of the Lemierre syndrome. J Clin Gastroenterol. 2003;37:196-7.

64. Clarke MG, Kennedy NJ, Kennedy K. Serious consequences of a sore throat. Ann R Coll Surg Engl. 2003;85:242-4.

65. Athavale NV, Leitch DG, Cowling P. Liver abscesses due to Fusobacterium spp that mimick malignant metastatic liver disease. Eur J Clin Microbiol Infect Dis. 2002;21:884-6.

66. Hwang J-J, Lau Y-J, Hu B-S, Shi Z-Y, Lin Y-H. Haemophilus parainfluenzae and Fusobacterium necrophorum liver abscess: a case report. J Microbiol Immunol Infect. 2002;35:65-7.

67. Narsinghani U, Schmidt MB, Jacobs RF, Anand KS. Radiological case of the month: Lemierre syndrome. Arch Pediatr Adolesc Med. 2001;155:965-6.

68. Stallworth JR, Carroll JM. Lemierre's syndrome: new insights into an old disease. Clin Pediatr (Phila). 1997;36:715-7.

69. Hagelskjaer L, Pedersen G. Fusobacterium necrophorum septicemia complicated by liver abscess. A case report. APMIS. 1993;101:904-6.

70. Zenon GJ, Cadle RM, Hamill RJ. Ampicillin-sulbactam therapy for multiple pyogenic hepatic abscesses. Clin Pharm. 1990;9:939-47.

71. Weed TE, Merritt CR, Bowen JC. Surgical management of multiple hepatic abscesses using ultrasonography for sequential evaluation. South Med J. 1982;75:1270-3

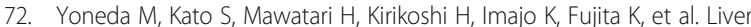
abscess caused by periodontal bacterial infection with Fusobacterium necrophorum. Hepatol Res. 2011:41:194-6.

73. Bytyci F, Khromenko E. Hepatic abscess caused by Fusobacterium necrophorum after a trip to the dentist. BMJ Case Rep. 2016;2016. doi:10.1136/bcr-2015-210235.

74. Goletti O, Angrisano C, Lippolis PV, Zocco G, Galatioto C, Lorenzetti L, et al. Percutaneous management of multiple bilateral liver abscesses complicating Crohn disease. Surg Laparosc Endosc Percutan Tech. 2001:11:131-3.

75. Posthuma EF, Bieger R, Kuypers TJ. A rare cause of a hepatic abscess: diverticulitis of the ileum. Neth J Med. 1993:42:69-72.

76. Gilbert VE. Anaerobic liver abscess: medical treatment. Ann Intern Med. 1973;78:303

\section{Submit your next manuscript to BioMed Central and we will help you at every step:}

- We accept pre-submission inquiries

- Our selector tool helps you to find the most relevant journal

- We provide round the clock customer support

- Convenient online submission

- Thorough peer review

- Inclusion in PubMed and all major indexing services

- Maximum visibility for your research

Submit your manuscript at www.biomedcentral.com/submit 